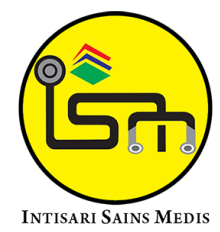

Published by Intisari Sains Medis

\section{Efektivitas pelatihan tutorial simulasi Early Warning Score (EWS) COVID-19 dewasa terhadap pengetahuan dan kinerja tenaga kesehatan dalam pendokumentasian di RSUD Sanjiwani, Gianyar, Indonesia}

\begin{abstract}
Ni Komang Ady Tri Hapsari ${ }^{1 *}$, I Gede Putu Darma Suyasa² ${ }^{2}$ Ni Putu Ayu Jelantik Sastamidhyani ${ }^{2}$, Ni Made Dewi Wahyunadi²
\end{abstract}

${ }^{1}$ Program Studi Magister Keperawatan, Fakultas Kesehatan, Institut Teknologi dan Kesehatan Bali, RSUD Sanjiwani, Gianyar, Bali, Indonesia; ${ }^{2}$ Fakultas Kesehatan, Institut Teknologi dan Kesehatan Bali, Bali, Indonesia;

\footnotetext{
*Korespondensi:

Ni Komang Ady Tri Hapsari;

Program Studi Magister Keperawatan, Fakultas Kesehatan, Institut Teknologi dan Kesehatan Bali, RSUD Sanjiwani Gianyar;

acihapsari90@gmail.com
}

Diterima: 03-08-2021

Disetujui: 29-09-2021

Diterbitkan: 12-10-2021

\section{ABSTRACT}

Background: Monitoring vital signs in COVID-19 patients with severe symptoms could be conducted by documenting Early Warning Score (EWS). However, health care workers are not trained to apply EWS. The purpose of this study was to determine the effectiveness of the adult EWS COVID-19 simulation tutorial training on the knowledge and performance of health workers in documentation.

Methods: The research method used was Quasi Experiment with a pre-test post-test approach with control design. Samples were 40 health workers divided into 2 groups. The intervention group 1 was the health workers from the Kamboja Room by providing simulation tutorial training consisting of the Tutorial (Lecture) method, case studies and simulations, while the intervention group 2 was the Arjuna Room health worker by providing the Tutorial (Lecture) method. Data

were analyzed using SPSS version 25 for Windows. Results: Therewasasignificant differencein knowledge and performance related to the documentation before and after training was carried out using the Wilcoxon Sign Rank Test $(p<0.001)$. In addition, a significant difference was also found in the effectiveness of the training method using the Independent T-Test test for knowledge $(p=0.041)$ and performance $(p=0.029)$ in documentation.

Conclusion: Simulation Tutorial Training is more effective in increasing knowledge and performance of health workers in documentation compared to Tutorial Training (Lecture). Based on the results of this study, it is recommended to provide training using the Adult COVID-19 EWS Simulation Tutorial method on an ongoing basis.

Keywords: COVID-19, Early Warning Score (EWS), Knowledge, Simulation.

Cite This Article: Hapsari, N.K.A.T., Suyasa, I.G.P.D., Sastamidhyani, N.P.A.J., Wahyunadi, N.M.D. 2021. Efektivitas pelatihan tutorial simulasi Early Warning Score (EWS) COVID-19 dewasa terhadap pengetahuan dan kinerja tenaga kesehatan dalam pendokumentasian di RSUD Sanjiwani, Gianyar, Indonesia. Intisari Sains Medis 12(3): 710-717. D0l: $10.15562 /$ ism.v12i3.1102

\title{
ABSTRAK
}

Latar Belakang: Monitoring tanda-tanda vital pada pasien dengan Coronavirus Disease-2019 (COVID-19) dengan gejala berat dapat dilakukan melalui pendokumentasian Early Warning Score (EWS). Namun, tenaga kesehatan belum mendapatkan pelatihan tentang EWS COVID-19. Penelitian ini bertujuan untuk mengetahui efektivitas pelatihan tutorial simulasi EWS COVID-19 dewasa terhadap pengetahuan dan kinerja tenaga kesehatan dalam pendokumentasian.

Metode: Desain penelitian ini adalah Quasieksperimental dengan pendekatan pre-test-post- test with control design. Sampel adalah 40 orang tenaga kesehatan yang terbagi dalam dua kelompok. Kelompok intervensi 1 yaitu tenaga kesehatan Ruang Kamboja dengan pemberian pelatihan tutorial simulasi yang terdiri dari metode Tutorial (Lecture), studi kasus, dan simulasi, sedangkan kelompok intervensi 2 yaitu tenaga kesehatan Ruang Arjuna dengan pemberian metode Tutorial (Lecture). Data dianalisis dengan SPSS versi 25 untuk Windows.

Hasil: Terdapat perbedaan yang bermakna antara pengetahuan dan kinerja dalam pendokumentasian 
sebelum dan setelah pelatihan dengan uji Wilcoxon Sign Rank Test $(p<0,001)$. Disamping itu juga terdapat perbedaan yang bermakna efektivitas metode pelatihan dengan uji Independent T-Test untuk pengetahuan $(p=0.041)$ dan untuk kinerja dalam pendokumentasian $(p=0.029)$.

Kesimpulan: Pelatihan Tutorial Simulasi lebih efektif dalam meningkatkan pengetahuan dan kinerja tenaga kesehatan dalam pendokumentasian dibandingkan dengan Pelatihan Tutorial (Lecture). Berdasarkan hasil penelitian ini disarankan untuk memberikan pelatihan dengan metode Tutorial Simulasi EWS COVID-19 dewasa secara berkesinambungan.

Kata kunci: COVID-19, Early Warning Score (EWS), Pengetahuan, Simulasi.

Sitasi Artikel ini: Hapsari, N.K.A.T., Suyasa, I.G.P.D., Sastamidhyani, N.P.A.J., Wahyunadi, N.M.D. 2021. Efektivitas pelatihan tutorial simulasi Early Warning Score (EWS) COVID-19 dewasa terhadap pengetahuan dan kinerja tenaga kesehatan dalam pendokumentasian di RSUD Sanjiwani, Gianyar, Indonesia. Intisari Sains Medis 12(3): 710-717. D0I: $10.15562 /$ ism.v12i3.1102

\section{PENDAHULUAN}

Angka kejadian penyakit Coronavirus Disease-2019 (COVID-19) di Indonesia semakin meningkat, bahkan pada kondisi yang mengkhawatirkan karena munculnya varian delta yang lebih mendominasi infeksi dengan tingkat hospitalisasi yang tinggi menggantikan varian alpha. ${ }^{1}$ Pasien COVID-19 dengan kondisi kritis berpotensi untuk mengalami kegagalan nafas dan kegagalan organ sehingga menyebabkan kematian. Oleh karena itu, pasien COVID-19 dengan risiko memburuk harus dirujuk pada perawatan yang lebih intensif dan kritis. ${ }^{2}$

Perawatan kritis adalah suatu perawatan khusus pada pasien yang dalam kondisi yang mengancam nyawa serta membutuhkan perawatan yang komprehensif, monitoring yang ketat dan biasanya berada di ruang Intensive Care Unit (ICU). ${ }^{3}$ Monitoring ketat dengan bantuan suatu alat prediksi dapat membantu mencegah kematian. ${ }^{4}$ Pengkajian harian dengan skor klinis yang telah divalidasi diperlukan untuk mengidentifikasi pasien yang berisiko mengalami perburukan dan untuk memandu pengambilan keputusan selama pandemi COVID-19, diantaranya adalah Early Warning Score (EWS). ${ }^{5}$

Manfaat EWS antara lain sebagai skor peringatan dan deteksi dini pasien dengan risiko perburukan, sebagai nilai prediksi dari admission dan readmission ke ICU, lama perawatan di ICU, kejadian henti jantung bahkan kematian. Melalui EWS perawat memfasilitasi komunikasi dengan dokter bahkan saat merujuk pasien sebagai upaya mendapat bantuan medis dan meminimalkan konflik. EWS semakin berkembang seiring dengan kemajuan teknologi dan terintegrasi dengan Electronic Health Record (EHR) membantu mencegah keterlambatan deteksi dini perburukan kondisi pasien. ${ }^{6}$ EWS memiliki peran yang sangat penting dalam menilai kondisi pasien. Namun, jika penilaiannya tidak dilakukan dengan benar, penilaian EWS dapat menambah beban kerja perawatan karena memerlukan pengkajian dan evaluasi ulang oleh perawat. Untuk mencegah hal tersebut terjadi, dibutuhkan perawat yang memiliki pengetahuan dan keterampilan untuk melakukan penilaian EWS. ${ }^{7}$

EWS untuk pasien COVID-19 Dewasa telah diterapkan di Wuhan dalam melakukan deteksi dini pasien dengan infeksi yang parah dan keputusan untuk dilakukan perawatan sesuai dengan derajat tingkat keparahan gejala. $^{8} \quad$ Skor pada EWS-COVID-19 merupakan modifikasi dari NEWS dengan penambahan parameter umur > 65 tahun sebagai faktor risiko tersendiri berdasarkan laporan terbaru, disamping 7 parameter lainnya yakni frekuensi pernafasan, saturasi oksigen, penggunaan oksigen tambahan, temperatur, tekanan darah sistolik, frekuensi nadi, dan tingkat kesadaran. ${ }^{2}$ Dengan penambahan parameter usia maka penilaian awal tepat waktu oleh pengambil keputusan klinis yang kompeten merupakan langkah yang tepat.

Penelitian oleh Damayanti $\mathrm{R}$ et al., menunjukkan program pelatihan tutorial (lecture) simulasi EWS sangat berpengaruh terhadap pengetahuan dan kinerja klinis perawat.9 Pelatihan ini termasuk dalam penelitian dengan pendekatan participant centered training dan merupakan pelatihan berbasis adult learning, dimana metode yang digunakan adalah metode simulasi disertai studi kasus. Metode ini dinilai lebih efektif dibandingkan pelatihan dengan pendekatan pengajaran (lecture-based training), walaupun keduanya termasuk dalam metode off the job training. ${ }^{10}$

Sehubungan dengan belum dikenalkannya EWS COVID-19 pada sebagian besar tenaga Kesehatan di Indonesia, peneliti tertarik melakukan penelitian untuk efektivitas pelatihan tutorial simulasi EWS COVID-19 dewasa terhadap pengetahuan dan kinerja tenaga kesehatan dalam pendokumentasian.

\section{METODE}

Jenis penelitian ini adalah penelitian kuantitatif dengan desain Quasieksperimental dengan pendekatan pretest-post-test with control design. Penelitian dilakukan di Ruang Isolasi Kamboja dan Arjuna RSUD Sanjiwani Gianyar pada tanggal 26 Maret-11 April 2021. Populasi yang diambil sebagai subjek penelitian adalah tenaga kesehatan di Ruang Isolasi Kamboja dan Arjuna RSUD Sanjiwani Gianyar berjumlah 53 orang. Kriteria inklusi dari penelitian ini adalah tenaga kesehatan yang bekerja di Ruang Isolasi dengan Pendidikan minimal D3. Kriteria eksklusi dari penelitian ini adalah kepala ruangan dan inventaris ruangan, tenaga kesehatan yang sedang menjalani cuti 
melahirkan atau cuti besar lain dan tenaga kesehatan yang sedang melanjutkan studi atau tugas belajar. Setelah dilakukan perekrutan sample, 40 orang responden berpartisipasi dalam penelitian yang terbagi ke dalam kelompok intervensi 1 (20 responden) dan kelompok intervensi 2 (20 responden).

Instrumen penelitian terdiri dari data demografi, kuesioner pengetahuan tentang EWS COVID-19 dewasa dengan jumlah 40 item pertanyaan tentang EWS COVID-19 dewasa, kuesioner kinerja dalam pendokumentasian EWS COVID-19 dewasa dengan jumlah 15 item pernyataan serta lembar observasi pendokumentasian EWS COVID-19 dewasa yang terdiri dari 15 item tindakan yang akan diobservasi. Uji validitas instrumen dilaksanakan face validity dan Content Validity Index (CVI) pada 5 expert yang dilaksanakan pada bulan Februari 2021 dengan nilai mean CVI pada masing-masing kuesioner adalah 1 . Serta dilaksanakan uji reliabilitas terhadap 30 responden di Ruang Isolasi Kedondong dan Jepun RSUD Klungkung pada bulan Maret 2021 dengan nilai Cronbach Alfa pada kuesioner Pengetahuan EWS COVID-19 Dewasa adalah 0.815 dan kuesioner kinerja dalam pendokumentasian EWS COVID-19 Dewasa adalah 0.912 .

Peneliti telah membuat dan melakukan review Modul Pelatihan Dokumentasi EWS COVID-19 bersama tim reviewer modul. Selanjutnya menetapkan jadwal, menjelaskan tentang tujuan, manfaat dan prosedur penelitian kepada Kepala ruangan, serta meminta izin mencari sampel penelitian. Jadwal pelatihan ditetapkan tanggal 26 - 27 Maret 2021.Dari hasil randomisasi ruangan, didapatkan hasil ruangan Kamboja sebagai kelompok intervensi 1 dan ruangan Arjuna sebagai kelompok intervensi 2, mengajukan informed consent kepada tenaga kesehatan ruang Kamboja dan Arjuna dan menetapkan sampel berdasarkan kriteria inklusi dan eksklusi dengan teknik pengambilan sampel (purposive sampling). Peneliti membentuk grup pelatihan pada Whatsapp masing-masing pada kelompok intervensi 1 dan 2. Melakukan pelatihan sesuai jadwal yang sudah ditentukan sesuai rundown acara yang telah disusun dalam Modul Pelatihan.
Sebelumnya, peneliti melakukan pre-test melalui media google form. Kelompok intervensi 1 diberikan pelatihan Tutorial Simulasi EWS COVID-19 dewasa yang terdiri dari metode Tutorial (Lecture), studi kasus dan simulasi pengisian chart EWS COVID-19 dengan daring (dalam jaringan) dengan zoom RSUD Sanjiwani Gianyar. Materi pelatihan diberikan dalam bentuk power point disertai suara oleh peneliti selama 90 menit. Setelah itu dilanjutkan dengan penyampaian video simulasi pengisian chart EWS COVID-19 berdasarkan kasus yang diberikan selama 30 menit. Kelompok intervensi 2 diberikan pelatihan EWS COVID-19 dewasa metode Tutorial (Lecture) dengan daring (dalam jaringan) dengan zoom RSUD Sanjiwani Gianyar selama 90 menit. Materi pelatihan diberikan dalam bentuk power point disertai suara oleh peneliti. Setelah pelatihan, peneliti melakukan posttest melalui media google form. Peserta pelatihan diwajibkan mengikuti protokol Kesehatan dengan memakai masker, menjaga jarak dengan peserta pelatihan lainnya saat pelatihan berlangsung (apabila peserta sedang berada di lingkungan RSUD Sanjiwani Gianyar). Peneliti mengundang expert pada saat pelatihan berlangsung. Peneliti melakukan observasi selama 7 hari, 2 minggu setelah pelatihan dilakukan tanggal 5-11 April 2021. Observasi penerapan pendokumentasian EWS COVID-19 dewasa pada kelompok intervensi 1 dan kelompok intervensi 2 dengan menggunakan lembar observasi, disertai pelaksanaan protokol kesehatan COVID-19 (Memakai masker, selalu mencuci tangan sebelum dan setelah observasi dilakukan, serta menjaga jarak saat proses observasi dilakukan).

Data dianalisis dengan menggunakan perangkat software computer SPSS versi 25 untuk Windows. Untuk mengetahui besarnya efektivitas metode pelatihan tutorial simulasi dan tutorial (lecture) EWS COVID-19 terhadap pengetahuan dan kinerja tenaga kesehatan dalam pendokumentasian EWS COVID-19, dipergunakan perhitungan nilai $\mathrm{N}$-Gain score. N-gain atau berdasarkan sumber asli dari artikel yang ditulis oleh Hake R tahun 1999 mengenalkan istilah Average normalized gain atau $\mathrm{N}$-gain rerata sebuah treatment, pembelajaran, perkuliahan merupakan sebuah ukuran kasar atau perkiraan mengenai keefektifan sebuah treatment, pembelajaran, perkuliahan dalam mendorong pemahaman konsep. ${ }^{11}$

\section{HASIL}

Karakteristik responden penelitian terhadap tenaga Kesehatan di 2 (dua) unit rawat inap isolasi tersebut diatas adalah umur, tingkat pendidikan dan lama bekerja yang dapat dilihat pada tabel 1 . Berdasarkan tabel 1 menunjukkan bahwa umur responden pada kedua kelompok intervensi lebih banyak berada pada rentang 41-45 tahun (30\%). Tingkat pendidikan kelompok intervensi 1 adalah ners (45\%) dan kelompok intervensi 2 adalah Diploma kebidanan (50\%). Lama bekerja responden pada kedua kelompok adalah $\geq 5$ tahun dengan persentase $60 \%$ kelompok intervensi 1 dan 75\% kelompok intervensi 2. Begitu juga jenis kelamin, mayoritas perempuan yaitu $60 \%$ pada kelompok intervensi 1 dan $90 \%$ pada kelompok intervensi 2.

Berdasarkan Tabel 2, sebanyak 8 orang $(40,0 \%)$ mampu menjawab pretest dengan baik dan terdapat 11 orang $(55,0 \%)$ yang menyelesaikan pre-test dengan nilai cukup, hanya ada 1 orang $(5,0 \%)$ yang kurang dalam menyelesaikan pre-test. Hal ini mendukung pencapaian kelompok tersebut pada post-test dimana semua responden $(100,0 \%)$ mampu meningkatkan pengetahuannya sehingga menyelesaikan post-test dengan baik.

Pada kelompok intervensi 2, terdapat 15 orang $(75,0 \%)$ yang menyelesaikan pretest dengan nilai cukup dan ditemukan $5(25,0 \%)$ orang yang kurang dalam penyelesaian pre-test. Selanjutnya pada kegiatan evaluasi dengan post-test, peneliti mendapatkan bahwa pengetahuan tentang EWS COVID 19 dewasa meningkat pada 19 orang $(95,0 \%)$. Mereka mampu mencapai nilai baik pada post-test namun masih ada 1 orang $(5,0 \%)$ yang belum mampu menyelesaikan post-test dengan baik.

Berdasarkan Tabel 2, sebanyak 15 orang $(75,0 \%)$ telah menunjukkan kinerja baik sebelum diberikan pelatihan, 4 orang $(20,0 \%)$ menunjukkan kinerja cukup dan sisanya 1 orang $(5,0 \%)$ memiliki kinerja kurang. Setelah diberikan pelatihan, kinerja kelompok intervensi 1 meningkat 
optimal, 20 orang responden (100,0\%) menunjukkan kinerja pendokumentasian EWS COVID 19 Dewasa dengan baik.

Pada kelompok intervensi 2, hanya 10 orang responden $(50,0 \%)$ menunjukkan kinerja pendokumentasian EWS COVID 19 Dewasa yang baik (50,0\%). Sisanya 8 orang $(40,0 \%)$ memiliki kinerja kurang

Tabel 1. Distribusi frekuensi karakteristik responden berdasarkan umur, tingkat Pendidikan dan lama bekerja di Ruang Isolasi Kamboja dan Arjuna RSUD Sanjiwani Gianyar tanggal 26 Maret-11 April 2021 $(n=40)$.

\begin{tabular}{|c|c|c|c|c|c|}
\hline \multirow[t]{2}{*}{ Karakteristik } & \multicolumn{2}{|c|}{$\begin{array}{c}\text { Kelompok } \\
\text { Intervensi } 1 \\
\end{array}$} & \multicolumn{2}{|c|}{$\begin{array}{c}\text { Kelompok } \\
\text { Intervensi } 2 \\
\end{array}$} & \multirow[t]{2}{*}{$\mathbf{P}$} \\
\hline & $\mathbf{N}=\mathbf{2 0}$ & $\%$ & $\mathrm{~N}=\mathbf{2 0}$ & $\%$ & \\
\hline \multicolumn{6}{|l|}{ Umur (Tahun) } \\
\hline $21-25$ & 4 & 20 & 1 & 5 & 0,776 \\
\hline $26-30$ & 4 & 20 & 4 & 20 & \\
\hline $31-35$ & 2 & 10 & 3 & 15 & \\
\hline $35-40$ & 3 & 15 & 5 & 25 & \\
\hline $41-45$ & 6 & 30 & 6 & 30 & \\
\hline $46-50$ & 1 & 5 & 1 & 5 & \\
\hline \multicolumn{6}{|l|}{ Tingkat Pendidikan } \\
\hline D3 Keperawatan & 8 & 40 & 3 & 15 & $0,002^{*}$ \\
\hline S1 Keperawatan & 2 & 10 & 4 & 20 & \\
\hline Ners & 9 & 45 & 3 & 15 & \\
\hline D3 Kebidanan & 0 & 0 & 10 & 50 & \\
\hline D4 Kebidanan & 1 & 5 & 0 & 0 & \\
\hline \multicolumn{6}{|l|}{ Lama Bekerja (Tahun) } \\
\hline$<1$ & 0 & 0 & 1 & 5 & 0,217 \\
\hline $1-3$ & 5 & 25 & 4 & 20 & \\
\hline $3-4$ & 3 & 15 & 0 & 0 & \\
\hline$\geq 5$ & 12 & 60 & 15 & 75 & \\
\hline \multicolumn{6}{|l|}{ Jenis Kelamin } \\
\hline Perempuan & 12 & 60 & 18 & 90 & 0,068 \\
\hline Laki-laki & 8 & 40 & 2 & 10 & \\
\hline
\end{tabular}

Tabel 2. Distribusi Pengetahuan dan Kinerja dalam Pendokumentasian EWS COVID-19 Dewasa di Ruang Isolasi Kamboja dan Arjuna RSUD Sanjiwani Gianyar.

\begin{tabular}{|c|c|c|c|c|}
\hline \multirow[t]{2}{*}{ Variabel } & \multicolumn{2}{|c|}{$\begin{array}{c}\text { Sebelum Intervensi } \\
\text { (Pre-test) }\end{array}$} & \multicolumn{2}{|c|}{$\begin{array}{c}\text { Sesudah intervensi } \\
\text { (Post-test) }\end{array}$} \\
\hline & $\mathbf{N}=\mathbf{2 0}$ & $\%$ & $\mathbf{N}=\mathbf{2 0}$ & $\%$ \\
\hline \multicolumn{5}{|l|}{ Pengetahuan } \\
\hline \multicolumn{5}{|c|}{ Kelompok Intervensi 1} \\
\hline Baik & 8 & 40,0 & 20 & 100,0 \\
\hline Cukup & 11 & 55,0 & 0 & 0,0 \\
\hline Kurang & 1 & 5,0 & 0 & 0,0 \\
\hline \multicolumn{5}{|c|}{ Kelompok Intervensi 2} \\
\hline Baik & 0 & 0,0 & 19 & 95,0 \\
\hline Cukup & 15 & 75,0 & 1 & 5,0 \\
\hline Kurang & 5 & 25,0 & 0 & 0,0 \\
\hline \multicolumn{5}{|c|}{ Kinerja Pendokumentasian } \\
\hline \multicolumn{5}{|c|}{ Kelompok Intervensi 1} \\
\hline Baik & 15 & 75,0 & 20 & 100,0 \\
\hline Cukup & 4 & 20,0 & 0 & 0,0 \\
\hline Kurang & 1 & 5,0 & 0 & 0,0 \\
\hline \multicolumn{5}{|c|}{ Kelompok Intervensi 2} \\
\hline Baik & 10 & 50,0 & 20 & 100,0 \\
\hline Cukup & 2 & 10,0 & 0 & 0,0 \\
\hline Kurang & 8 & 40,0 & 0 & 0,0 \\
\hline
\end{tabular}

dan 2 orang $(10,0 \%)$ memiliki kinerja cukup. Kinerja dalam pendokumentasian EWS COVID-19 sesudah diberikan pelatihan pada kelompok intervensi 2 juga mengalami peningkatan yang sangat baik yaitu semua responden mampu meningkatkan kinerja pendokuemntasian EWS COVID 19 dengan baik (Tabel 2).

Berdasarkan Tabel 3 menunjukkan bahwa sesudah dilakukan uji Wilcoxon didapatkan pengetahuan mengalami kenaikan nilai median yang bermakna dari $72,50 \quad(52,50-78,00) \quad$ (pre-test) menjadi $90,00 \quad(80,00-97,50) \quad$ (posttest $)(\mathrm{p}<0,001)$ sebelum dan setelah diberikan pelatihan tutorial simulasi EWS COVID-19 Dewasa pada kelompok intervensi 1. Pada kelompok intervensi 2 pengetahuan mengalami kenaikan nilai median yang bermakna dari $65,00(42,50-$ $70,00)$ (pre-test) menjadi 82,50 (72,50$87,50)$ (post-test) $(\mathrm{p}<0,001)$ sebelum dan setelah diberikan pelatihan tutorial EWS COVID-19 Dewasa (Tabel 3).

Hasil uji Wilcoxon juga menunjukkan bahwa kinerja dalam pendokumentasian mengalami kenaikan nilai median secara bermakna dari 52,50 $(30,00-58,00)$ (pretest) menjadi 58,00 (48,00-60,00) (posttest $) \quad(\mathrm{p}<0,001)$ sebelum dan setelah diberikan pelatihan tutorial simulasi EWS COVID-19 Dewasa pada kelompok intervensi 1 (Tabel 3). Pada kelompok intervensi 2 juga didapatkan kenaikan nilai median yang bermakna pada kinerja dalam pendokumentasian dari $44,50 \quad(21,00-58,00) \quad$ (pre-test) menjadi $54,50 \quad(45,00-60,00) \quad$ (post-test) $(\mathrm{p}<0,001)$ sebelum dan setelah diberikan pelatihan tutorial EWS COVID-19 Dewasa (Tabel 3).

Pelatihan tutorial simulasi EWS COVID-19 Dewasa cukup efektif untuk meningkatkan pengetahuan tenaga Kesehatan tentang EWS COVID-19 Dewasa. Sementara pelatihan tutorial EWS COVID-19 kurang efektif untuk meningkatkan pengetahuan tenaga Kesehatan tentang EWS COVID-19 Dewasa. Perbedaan efektivitas dari kedua pelatihan dilakukan uji Independent T-Test. Dari uji Independent T-Test didapatkan perbedaan yang bermakna pada $N$-Gain score pelatihan tutorial simulasi $(0,651 \pm 0,207)$ dan pelatihan tutorial $(0,537 \pm 0,119)(\mathrm{p}=0,041)$ terhadap 


\section{Tabel 3. Analisis Perbedaan Pengetahuan dan Kinerja dalam Pendokumentasian EWS COVID-19 Dewasa sebelum dan sesudah Pelatihan di RSUD Sanjiwani Gianyar.}

\begin{tabular}{|c|c|c|c|c|}
\hline \multirow{3}{*}{ Variabel } & \multicolumn{4}{|c|}{ Kelompok $(\mathrm{N}=40)$} \\
\hline & \multicolumn{2}{|c|}{ Intervensi 1 ( $\mathbf{N}=\mathbf{2 0})$} & \multicolumn{2}{|c|}{ Intervensi $2(\mathrm{~N}=\mathbf{2 0})$} \\
\hline & Median & Min-Maks & Median & Min-Maks \\
\hline \multicolumn{5}{|l|}{ Pengetahuan } \\
\hline Pre-test & 72,50 & $52,50-78,00$ & 65,00 & $42,50-70,00$ \\
\hline Post-test & 90,00 & $80,00-97,50$ & 82,50 & $72,50-87,50$ \\
\hline Nilai Z & \multicolumn{2}{|c|}{$-3,927$} & \multicolumn{2}{|c|}{$-3,941$} \\
\hline $\mathrm{p}$ & \multicolumn{2}{|c|}{$<0,001^{\star}$} & \multicolumn{2}{|c|}{$<0,001^{\star}$} \\
\hline \multicolumn{5}{|l|}{ Kinerja Pendokumentasian } \\
\hline Pre test & 52,50 & $30,00-58,00$ & 44,50 & $21,00-58,00$ \\
\hline Post test & 58,00 & $48,00-60,00$ & 54,50 & $45,00-60,00$ \\
\hline Nilai Z & \multicolumn{2}{|c|}{$-2,074$} & \multicolumn{2}{|c|}{$-2,846$} \\
\hline $\mathrm{P}$ & \multicolumn{2}{|c|}{$<0,001^{\star}$} & \multicolumn{2}{|c|}{$<0,001^{\star}$} \\
\hline
\end{tabular}

${ }^{\star}$ Uji Wilcoxon: Berbeda bermakna apabila nilai p kurang dari 0,05; Min: Minimum; Maks: Maksimum

Tabel 4. Analisis Efektivitas Pelatihan Tutorial Simulasi EWS COVID-19 Dewasa dan Pelatihan Tutorial terhadap Pengetahuan dan Kinerja dalam Pendokumentasian EWS COVID-19 Dewasa di RSUD Sanjiwani Gianyar.

\begin{tabular}{lccccc}
\hline \multirow{2}{*}{ Variabel } & \multicolumn{2}{c}{ Intervensi $\mathbf{1}(\mathbf{n = 2 0})$} & \multicolumn{2}{c}{ Intervensi $\mathbf{2}(\mathbf{n}=\mathbf{2 0})$} & \multirow{2}{*}{$\mathbf{p}$} \\
\cline { 2 - 5 } & Rerata & SB & Rerata & SB & \\
\hline Pengetahuan & 0,651 & 0,207 & 0,537 & 0,119 & $0,041^{*}$ \\
Kinerja Pendokumentasian & 0,771 & 0,195 & 0,619 & 0,226 & $0,029^{*}$ \\
\hline
\end{tabular}

${ }^{\star}$ Independent T-Test: berbeda bermakna apabila nilai p kurang dari 0,05; SB: Simpang Baku

pengetahuan (Tabel 4). Disamping itu, uji Independent T-Test juga menunjukkan perbedaan yang bermakna pada $\mathrm{N}$-Gain score pelatihan tutorial simulasi $(0,771 \pm 0,195)$ dan pelatihan tutorial $(0,619 \pm 0,226) \quad(\mathrm{p}=0,029) \quad$ terhadap kinerja dalam pendokumentasian EWS COVID-19 Dewasa (Tabel 4).

\section{PEMBAHASAN}

Tingkat pendidikan perawat dan bidan dalam penelitian ini mayoritas adalah Ners (45\%) dan Ahli Madya Kebidanan (50\%). Penelitian oleh Yunding J et al., didapatkan responden dengan persentase $58,1 \%$ adalah DIII Keperawatan dan $41.9 \%$ adalah Ners. ${ }^{12}$ Sedangkan penelitian oleh Damayanti $\mathrm{R}$ et al., mayoritas responden adalah DIII Keperawatan (81\%) dan Ners (19\%). ${ }^{9}$ EWS pada awalnya tersedia untuk profesi kebidanan, dan telah berkembang untuk mengidentifikasi kondisi awal, mencegah kondisi perburukan pasien serta meningkatkan angka keselamatan pasien sehingga dapat pula digunakan untuk profesi keperawatan. ${ }^{13}$ Saat ini di Ruang Isolasi COVID-19 RSUD Sanjiwani Gianyar, mayoritas perawat memiliki pendidikan sarjana keperawatan dengan profesi Ners. Begitu pula bidan di Ruang Isolasi RSUD Sanjiwani Gianyar memiliki pendidikan kebidanan yang mayoritas pada pendidikan vokasi yaitu DIII kebidanan. Hal ini dikarenakan Ruang Isolasi Kamboja merawat pasien COVID-19 dewasa derajat sedang, berat hingga kritis, sedangkan Ruang Isolasi Arjuna merawat pasien COVID-19 dewasa, anak dan kebidanan derajat sedang hingga berat.

Lama bekerja responden dalam penelitian ini mayoritas $\geq 5$ tahun yaitu $60 \%$ pada kelompok intervensi 1 dan $75 \%$ pada kelompok intervensi 2. Penelitian oleh Spangfors $M$ et al., dengan mayoritas perawat memiliki pengalaman $>10$ tahun. ${ }^{14}$ Namun didapatkan hasil penelitian bahwa semakin pendek pengalaman kerja, semakin besar proporsi perawat dalam menjawab positif tentang pengaplikasian EWS dan melakukan prioritas pasien dengan lebih baik yakni sebesar $83 \%$ pada perawat dengan lama bekerja 0-2 tahun..$^{14}$ Hasil penelitian ini didukung oleh teori yang menyatakan bahwa pengalaman dalam bekerja akan memberikan pengetahuan dan keterampilan yang profesional. Selain itu, hal yang mempengaruhi penerapan suatu praktik keperawatan selain pengetahuan adalah lama bekerja, beban kerja, motivasi dan supervise. ${ }^{15}$

Pengetahuan pada kelompok intervensi 1 sebelum diberikan pelatihan tutorial simulasi EWS COVID-19 Dewasa dengan mayoritas kategori cukup sebesar $55 \%$. Sesudah diberikan pelatihan tutorial simulasi EWS COVID-19 Dewasa didapatkan nilai pengetahuan dalam kategori baik yakni sebesar $100 \%$. Penelitian sebelumnya oleh Damayanti $\mathrm{R}$ et al., didapatkan pengetahuan tentang EWS sebelum dilakukan intervensi pada kelompok perlakuan dan kontrol berada pada kategori kurang masingmasing sebesar $64,2 \%$ dan 85,7\%. ${ }^{9}$ Setelah diberikan intervensi, terjadi peningkatan nilai pengetahuan menjadi kategori baik yaitu sebesar $57,1 \%$ pada kelompok intervensi dan kategori cukup pada kelompok kontrol dengan persentase sebesar $52,4 \%$. Sebanyak 8 orang (40\%) tenaga kesehatan di Ruang Kamboja pernah mengikuti pelatihan yang berkaitan tentang Triage, EWS dan BLS di masa Pandemi COVID-19 yang diselenggarakan oleh DPD PPNI Gianyar tahun 2020.

Berdasarkan hasil penelitian ini, didapatkan peningkatan nilai pengetahuan sebelum dan sesudah diberikan pelatihan tutorial simulasi EWS COVID-19. Uji Wilcoxon Sign Rank Test menunjukkan hasil yang berbeda bermakna dalam nilai pengetahuan EWS COVID-19 Dewasa sebelum dan setelah diberikan pelatihan tutorial simulasi EWS COVID-19 Dewasa pada kelompok intervensi 1. Hasil penelitian ini tidak jauh berbeda dengan penelitian Damayanti $\mathrm{R}$ et al., dimana ditemukan perbedaan bermakna nilai pengetahuan EWS pada kelompok intervensi. ${ }^{9}$ Pelatihan tutorial simulasi tentang EWS dapat meningkatkan pengetahuan perawat. Pengetahuan perawat tentang perburukan pasien terutama dalam initial assessment mempengaruhi perawat dalam menerapkan EWS. Berdasarkan 
hasil penelitian oleh Prihati DR dan Wirawati MK yang menyatakan bahwa terdapat hubungan yang bermakna antara pengetahuan tentang initial assessment dengan penerapan EWS. ${ }^{16} \mathrm{Hal}$ tersebut menunjukkan bahwa perawat yang memiliki pengetahuan tinggi akan mempengaruhi keterampilan dalam mengaplikasikan EWS.

Pengetahuan merupakan faktor utama seseorang dalam upaya mencapai suatu tingkatan keterampilan tertentu yang mampu didapatkan dengan latihanlatihan tertentu. ${ }^{17}$ Pengetahuan perawat dapat menurun seiring berkembangnya ilmu pengetahuan dan waktu, oleh karena itu diperlukan suatu Pendidikan dan pelatihan guna meningkatkan kualitas pengetahuan perawat. ${ }^{18}$

Pendidikan tenaga kesehatan dianjurkan untuk meningkatkan kompetensi dalam perawatan pasien dalam kondisi perburukan. ${ }^{19}$ Pendidikan, pelatihan dan kompetensi menjadi syarat mutlak yang harus dimiliki oleh tenaga kesehatan dalam menangani pasien dengan kondisi akut serta kompetensi management airway pada pasien dengan kondisi kritis dan atau memiliki nilai EWS lebih dari sama dengan 7.2 Efektivitas suatu program pendidikan dinilai dari pengetahuan dan kinerja tenaga kesehatan dalam pengidentifikasian, pengenalan dan pemberitahuan kondisi kritis pasien, begitu juga dalam pendekatan komunikasi melalui Situation, Background, Assessment, Recommendation (SBAR). ${ }^{20}$ Pendidikan berbasis website dikatakan oleh Liaw SY et al., dapat meningkatkan pengetahuan serta kinerja perawat dalam menilai, mengelola dan melaporkan kondisi klinis pasien dengan perburukan. ${ }^{21}$

Pelatihan tutorial simulasi merupakan pelatihan yang dilakukan dengan menggabungkan dua metode, dimana pelatihan tutorial (lecture) diberikan terlebih dahulu diikuti dengan pelatihan simulasi. Kemampuan abstrak didapat dengan pelatihan tutorial, sementara kemampuan konkrit didapat dengan pelatihan simulasi. ${ }^{9}$ Menurut Ozeckin LR et al., program pendidikan berbasis simulasi merupakan salah satu implementasi keperawatan untuk meningkatkan keselamatan pasien. ${ }^{20}$ Dari hasil penelitiannya, didapatkan bahwa metode ini mampu meningkatkan pengenalan dan perawatan pasien dalam kondisi perburukan. Selain itu, memberikan pengaruh positif terhadap persepsi diri, kepercayaan diri dan kenyamanan dalam berkomunikasi dengan tenaga kesehatan lainnya dalam menangani pasien, terutama pada pasien dengan kondisi kritis. Hal ini diperkuat oleh Liaw SY et al., yang menunjukkan program simulasi berbasis website dapat meningkatkan pengetahuan perawat tentang pengenalan dan implementasi pada kondisi perburukan pasien serta digunakan sebagai sarana pendidikan perawat dalam menangani kondisi kemunduran klinis pasien. ${ }^{19}$

Pelatihan tutorial simulasi efektif dalam meningkatkan kinerja tenaga Kesehatan dalam pendokumentasian EWS COVID-19 dewasa dengan nilai rata-rata Normalized-Gain Score adalah sebesar 0,77. Sedangkan pelatihan tutorial dianggap cukup efektif dalam meningkatkan kinerja tenaga kesehatan dalam pendokumentasian EWS COVID-19 dewasa dengan nilai rata-rata Normalized-Gain Score adalah sebesar 0,61 . Hasil Uji Independent T-Test terdapat perbedaan efektivitas yang bermakna antara pelatihan tutorial simulasi pada kelompok intervensi 1 dengan pelatihan tutorial (lecture) pada kelompok intervensi 2 terhadap kinerja tenaga Kesehatan dalam Pendokumentasian EWS COVID-19 Dewasa. Hasil penelitian ini sama dengan penelitian oleh Damayanti R et al., dimana didapatkan skor delta pre-test dan posttest performa klinis antar kelompok sebesar 20 (kelompok intervensi) dan 12 (kelompok kontrol) secara bermakna. ${ }^{9}$

Keberhasilan suatu pelatihan dipengaruhi oleh berbagai faktor diantaranya tersedianya modul pelatihan, materi pelatihan yang menarik, metode pelatihan, karakteristik situasional, karakteristik fasilitator dalam pelaksanaan pelatihan, karakteristik subjek pelatihan seperti kondisi awal peserta pelatihan serta kesungguhan peserta dalam mengikuti pelatihan partisipasi aktif peserta dalam mengikuti pelatihan. ${ }^{22} \mathrm{Hal}$ ini didukung penelitian oleh Andriana SF bahwa metode pelatihan merupakan salah satu faktor yang melatarbelakangi keberhasilan suatu pelatihan disamping latar belakang pendidikan formal terakhir, kemampuan instruktur dan dukungan sarana dan prasarana. ${ }^{23}$

Pada pelatihan ini, fasilitator memberikan materi yang menarik dan belum pernah diterima oleh peserta pelatihan. Materi yang diberikan sangat penting untuk diketahui peserta dalam menunjang pemberian asuhan keperawatan kepada pasien COVID-19. Antusiasme dan penerimaan peserta pelatihan dalam mengikuti jalannya pelatihan juga sangat berpengaruh dalam keefektifan materi pelatihan yang diberikan. Penerapan modul pelatihan yang berisi proses jalannya pelatihan dan materi lengkap tentang EWS COVID-19 membantu peserta dalam mengikuti proses pelatihan dan memahami konsep materi EWS COVID-19 sehingga terjadi peningkatan pengetahuan dan kinerja dalam pendokumentasian EWS COVID-19 Dewasa.

Penelitian ini serupa dengan yang diungkapkan oleh Saab MM et al., bahwa program pendidikan dan pelatihan keperawatan baik dengan berbasis web maupun simulasi pengenalan bagan EWS menunjukkan peningkatan pengetahuan kepada perawat. ${ }^{24}$ Begitu pula terdapat peningkatan kinerja klinis perawat dalam melakukan dokumentasi tanda-tanda vital yang akurat dan lengkap, perhitungan EWS yang tepat dan respon yang tepat sesuai kemunduran klinis pasien. ${ }^{24}$ Namun dalam penelitian oleh Ludikhuize J et al., didapatkan bahwa perawat yang mengikuti pelatihan EWS (77\%) tidak secara bermakna dapat mengidentifikasi dan mengetahui respon yang tepat terhadap kerusakan klinis pasien dibandingkan perawat yang tidak mengikuti pelatihan (43\%). ${ }^{25}$ Begitu pula dengan Kyriacos U et al., yang menemukan bahwa pelatihan EWS tidak terkait dengan perubahan yang signifikan pada respon perawat terhadap kerusakan klinis pasien. ${ }^{7}$

Hasil observasi pendokumentasian EWS COVID-19 Dewasa selama 7 hari pada kelompok intervensi 1 berada pada kategori baik (100\%) sedangkan pada kelompok intervensi 2 mayoritas pada kategori baik (80\%) dan sisanya kategori cukup (20\%). Menurut Saab MM et al., pencatatan TTV meningkat secara signifikan setelah dilakukan pendidikan 
dan pelatihan bagan observasi EWS. ${ }^{24}$

Observasi pada penelitian ini dilakukan 14 hari setelah pelatihan selama 7 hari pada kedua ruangan intervensi. Observasi dilakukan oleh peneliti langsung tanpa diwakilkan menggunakan lembar observasi. Peneliti memiliki progress note untuk mengetahui temuan, rencana dan kontrak berikutnya dari observasi tersebut. Observasi dilakukan pada responden sesuai dengan shift jaga responden dan sesuai dengan metode penugasan responden yaitu metode tim-modifikasi. Hasil observasi berupa lembar dokumentasi penerapan EWS COVID-19 yang dilakukan kepada setiap pasien sebanyak 40 dokumen. Observasi penerapan EWS COVID-19 Dewasa sangat penting dilakukan mengingat ruang rawat inap pasien COVID-19 merupakan ruangan dengan long term care. Dimana pasien dilakukan isolasi dan mendapatkan terapi sesuai derajat keparahan pasien.

Dalam pelaksanaan observasi, didapatkan temuan bahwa responden masih belum terbiasa melakukan penilaian EWS COVID-19 dewasa dan memerlukan waktu yang cukup lama dalam pelaksanaan pendokumentasian EWS COVID-19 Dewasa. Jumlah pasien yang cukup banyak disertai beban kerja yang cukup berat menjadi kendala dalam pelaksanaan penerapan EWS COVID-19 dewasa. Responden berharap penilaian EWS COVID-19 dewasa dapat tersinkronisasi dengan Sistem Informasi Rumah Sakit Sanjiwani Gianyar (SIMRS) agar lebih efisien waktu terutama dalam pendokumentasian EWS COVID-19 Dewasa serta ditetapkannya Standar Operasional Prosedur (SOP) monitoring EWS COVID-19 di Ruang Perawatan pasien COVID-19.

Keterbatasan dalam penelitian ini adalah penelitian ini menggunakan sampel terkecil dari suatu penelitian dengan kekuatan sampel yang rendah berdasarkan perhitungan aplikasi $G$ Power, ruangan lokasi penelitian dengan 2 (dua) karakteristik tempat perawatan pasien COVID-19 yang berbeda, peneliti tidak mengontrol variabel perancu dari penelitian ini terutama pada karakteristik responden penelitian dari segi tingkat pendidikan yang tidak homogen, waktu penilaian observasi pendokumentasian
EWS COVID-19 Dewasa dilakukan sesuai dengan shift peneliti sehingga hasil observasi kurang maksimal dan metode pelatihan yang diberikan melalui daring atau online sempat terkendala sinyal sehingga mengganggu jalannya pelatihan.

\section{SIMPULAN}

Berdasarkan hasil penelitian, maka dapat disimpulkan bahwa terdapat perbedaan pengetahuan dan kinerja dalam pendokumentasian EWS COVID-19 yang signifikan pada kelompok intervensi 1 dan kelompok intervensi 2 dengan nilai signifikansi masing-masing adalah $<0.001$ pada uji Wilxocon Signed Rank Test. Sedangkan berdasarkan uji Independent T-Test, terdapat perbedaan bermakna pengetahuan dan kinerja dalam pendokumentasian EWS COVID-19 antara kelompok 1 dan 2 antara pelatihan tutorial simulasi dengan pelatihan tutorial (Lecture) terhadap pengetahuan tenaga kesehatan tentang EWS COVID-19 Dewasa.

\section{KONFLIK KEPENTINGAN}

Penulis menyatakan tidak memiliki konflik kepentingan terkait publikasi dari penelitian ini.

\section{PERSETUJUAN ETIK}

Penelitian ini telah mendapatkan persetujuan etik atau Ethical Clereance dari Komite Etik Penelitian ITEKES Bali no. 03.103/KEPITEKES-BALI/II/2021 tanggal 24 Februari 2021 dan Panitia Etik Penelitian Kesehatan RSUD Sanjiwani Gianyar no. 20/PEPK/III/2021 tanggal 4 Maret 2021. Serta telah mendapat ijin penelitian dari RSUD Sanjiwani Gianyar dengan nomor surat 070/5700/RSU tanggal 6 Maret 2021.

\section{PENDANAAN}

Penulis menyatakan mendapatkan pendanaan secara swadana tanpa melibatkan pihak sponsor manapun.

\section{KONTRIBUSI PENULIS}

Seluruh penulis memiliki kontribusi yang sama dalam penyusunan konsep, desain, definisi konten intelektual; melakukan pencarian literatur, studi klinis, studi eksperimental, akuisisi data, analisis data, analisis statistik; menyusun, memperbaiki dan menyelaraskan manuskrip untuk publikasi pada jurnal ilmiah.

\section{DAFTAR PUSTAKA}

1. Hikmawati I, Setiyabudi R. Epidemiology of COVID-19 in Indonesia: common source and propagated source as a cause for outbreaks. J Infect Dev Ctries. 2021;15(5):646-652.

2. Kostakis I, Smith GB, Prytherch D, Meredith P, Price C, Chauhan A, et al. The performance of the National Early Warning Score and National Early Warning Score 2 in hospitalised patients infected by the severe acute respiratory syndrome coronavirus 2 (SARS-CoV-2). Resuscitation. 2021;159:150-157.

3. Namendys-Silva SA, Cherit GD. Recommendations for the management of critically ill adult patients with COVID-19. Recomendaciones de tratamiento para pacientes adultos graves con COVID-19. Gac Med Mex. 2020;156(3):246-248.

4. Weng Z, Chen Q, Li S, Li H, Zhang Q, Lu S, et al. ANDC: an early warning score to predict mortality risk for patients with Coronavirus Disease 2019. J Transl Med. 2020;18(1):328.

5. Myrstad M, Ihle-Hansen H, Tveita AA, Andersen EL, Nygård S, Tveit A, et al. National Early Warning Score 2 (NEWS2) on admission predicts severe disease and in-hospital mortality from Covid-19 - a prospective cohort study. Scand J Trauma Resusc Emerg Med. 2020;28(1):66.

6. Downey CL, Tahir W, Randell R, Brown JM, Jayne DG. Strengths and limitations of early warning scores: A systematic review and narrative synthesis. Int $J$ Nurs Stud. 2017;76:106-119.

7. Kyriacos U, Jelsma J, Jordan S. Monitoring vital signs using early warning scoring systems: a review of the literature. J Nurs Manag. 2011;19(3):311-330.

8. Liao X, Wang B, Kang Y. Novel coronavirus infection during the 2019-2020 epidemic: preparing intensive care units-the experience in Sichuan Province, China. Intensive Care Med. 2020;46(2):357-360.

9. Damayanti R, Trisyani Y, Nuraeni A. Effects of Early Warning Score (EWS) Tutorial Simulation on Nurses' Knowledge and Clinical Performance. Nurse Media Journal of Nursing. 2019;9(2):231-241.

10. Rahmi H, Suryalena. Pengaruh On the Job Training dan Off the Job Training terhadap Kinerja Karyawan (Studi Pada Karyawan Bagian Kantor PTPN V Unit Kebun Lubuk Dalam Kabupaten Siak). Jurnal Online Mahasiswa Fakultas Ilmu Sosial dan Ilmu Politik Universitas Riau. 2017;4(2):1-12.

11. Hake R. Analyzing Change/Gain Score. Indiana: Indiana University. 1999.

12. Yunding J, Haerianti M, Evidamayanti E, Evawaty E, Indrawati I. Pemberdayaan Perawat dalam Penerapan Nurse Early Warning System untuk Memantau Kondisi Pasien di Rumah 
Sakit. Jurnal Abdimas Kesehatan (JAK). 2020;2(2):135-138.

13. Fox A, Elliott N. Early warning scores: a sign of deterioration in patients and systems. Nurs Manag (Harrow). 2015;22(1):26-31.

14. Spångfors $M$, Molt $M$, Samuelson $K$. National Early Warning Score: A survey of registered nurses' perceptions, experiences and barriers. J Clin Nurs. 2020;29(7-8):1187-1194.

15. Ekawati FA, Saleh MJ, Astuti AS. Hubungan Pengetahuan Perawat Tentang NEWSS dengan Penerapannya. Jurnal Ilmiah Kesehatan Sandi Husada. 2020;11(1):413-422.

16. Prihati DR, Wirawati MK. Pengetahuan Perawat tentang Early Warning Score dalam Penilaian Dini Kegawatan Pasien Kritis. Jurnal Keperawatan. 2019;11(4):237-242.

17. Sudiwedani A, Darma GS. Analysis of the effect of knowledge, attitude, and skill related to the preparation of doctors in facing industrial revolution 4.0. Bali Medical Journal. 2020;9(2):524-530.

18. Kartikasari F, Yani A, Azidin Y. Pengaruh Pelatihan Pengkajian Komprehensif terhadap Pengetahuan dan Keterampilan Perawat
Mengkaji Kebutuhan Klien di Puskesmas. Jurnal Keperawatan STIKES Suaka Insan. 2020;5(1):79-78.

19. Liaw SY, Wong LF, Lim EY, Ang SB, Mujumdar $\mathrm{S}$, Ho JT, et al. Effectiveness of a Web-Based Simulation in Improving Nurses' Workplace Practice With Deteriorating Ward Patients: A Pre- and Postintervention Study. J Med Internet Res. 2016;18(2):e37.

20. Ozekcin LR, Tuite P, Willner K, Hravnak M. Simulation education: early identification of patient physiologic deterioration by acute care nurses. Clin Nurse Spec. 2015;29(3):166-173.

21. Liaw SY, Wong LF, Chan SW, Ho JT, Mordiffi SZ, Ang SB, et al. Designing and evaluating an interactive multimedia Web-based simulation for developing nurses' competencies in acute nursing care: randomized controlled trial. J Med Internet Res. 2015;17(1):e5.

22. Pratiwi TV, Wahyuningsih H, Rumiani. Pelatihan Kebersyukuran untuk Menurunkan Tingkat Stres pada Pasien Diabetes Mellitus Tipe 2. Nathiqiyyah: Jurnal Psikologi Islam. 2018;1(1):1-26.
23. Andriana SF. Analisis Faktor-Faktor Yang Mempengaruhi Keberhasilan Pelatihan Umkm Di Kecamatan Srandakan Kabupaten Bantul Yogyakarta [Skripsi]. Universitas PGRI Yogyakarta. 2016.

24. Saab MM, McCarthy B, Andrews T, Savage E, Drummond FJ, Walshe N, et al. The effect of adult Early Warning Systems education on nurses' knowledge, confidence and clinical performance: A systematic review. J Adv Nurs. 2017;73(11):2506-2521.

25. Ludikhuize J, de Jonge E, Goossens A. Measuring adherence among nurses one year after training in applying the Modified Early Warning Score and Situation-Background-AssessmentRecommendation instruments. Resuscitation. 2011;82(11):1428-1433.

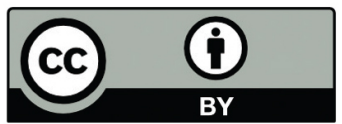

This work is licensed under a Creative Commons Attribution 